Eastern Illinois University

The Keep

Faculty Research and Creative Activity

Economics

January 2013

\title{
Patterns of technology transfer among the Arab Gulf States: opportunities and challenges
}

Dean S. Elmuti

Eastern Illinois University

Ahmed Abou-Zaid

Eastern Illinois University, asabouzaid@eiu.edu

Follow this and additional works at: http://thekeep.eiu.edu/economics_fac

Part of the Business Commons, and the Economics Commons

\section{Recommended Citation}

Elmuti, Dean S. and Abou-Zaid, Ahmed, "Patterns of technology transfer among the Arab Gulf States: opportunities and challenges" (2013). Faculty Research and Creative Activity. 8.

http://thekeep.eiu.edu/economics_fac/8

This Article is brought to you for free and open access by the Economics at The Keep. It has been accepted for inclusion in Faculty Research and Creative Activity by an authorized administrator of The Keep. For more information, please contact tabruns@eiu.edu. 


\title{
Patterns of technology transfer among the Arab Gulf States: opportunities and challenges
}

\author{
Dean S. Elmuti \& Ahmed S. Abou-Zaid
}

\begin{abstract}
Purpose - The purpose of this paper is to investigate the incentives, options, and obstacles to transfer technology to the Arab Gulf region.

Design/methodology/approach - A validated and reliable instrument was used to gather data from former expatriates who were employed by American-based multinational corporations.
\end{abstract}

Findings - The results indicate that the Arab Gulf States possess a wide range of resources and incentives offered to investors which contribute to the Gulf's attractiveness. At the same time, however, industrialization efforts, including transfer of technology to the Gulf region, are hampered by lack of industrial management expertise and technical skills among the relatively small national population and by resistance to new forms of technology by local residents.

Research limitations/implications - Technology transfer cannot be seen as the only resort for attaining growth rates. Education, innovation, and basic science are necessary to achieve economic development. In addition, the Arab Gulf States must address serious demographic challenges.

Originality/value - This exploratory, empirical investigation provides insight into the opportunities and challenges of technology transfer to the Gulf region. It identifies areas that need further investigation.

Keywords: Technology transfer, Technology challenges, Technology effectiveness, Technology opportunities

Introduction It is widely recognized that multinational enterprises (MNEs) and foreign direct investment (FDI) are the most important channels through which technology can be transferred across countries. The process of the acquisition of technology and its diffusion is known to be very crucial for fostering growth via increasing total factor productivity and capital accumulation and enhancing economic and social development in the developing economies (Cipollina et al., 2011; Motohashi and Yuan, 2010; Wang, 2009). The acquisition of foreign technologies by East Asia's newly industrialized countries coupled with domestic "technological learning" are clear evidence of how technology transfer has been one of the key factors in their rapid technological and economic development. In fact, the importance of technology transfer to growth is not new. More than three decades ago Mansfield (1975) pointed out, "One of the fundamental processes that influences the economic performance of nations and firms is technology transfer": 
Economists have long recognized that the transfer of technology is at the heart of the process of economic growth and that the progress of both developed and developing countries depend on the extent and efficiency of such transfer.

Dinopoulos and Segerstrom (2010), among others, report that technology transfer is a comprehensive term covering mechanisms for shifting information across borders and its effective diffusion into recipient or host economies. Chiesa and Manzini (2009) and Blalock and Gertler (2004) divide technology transfer into three successive stages. The first focuses on providing machinery and equipment to the host country for the purpose of manufacturing. The second stage emphasizes the use of better and modern managerial, marketing, and personal skills as a result of technology diffusion. The third stage recognizes the importance of education and training about the new technology so that the new possessors can adequately handle the new technology. Technology transfer cannot be seen as the only resort for attaining growth rates. Education, innovation, and domestic research and development processes are necessary to achieve some economic growth. However, understanding the challenges and opportunities of technology transfer among the Arab Gulf States and the role of multinational corporations in the economic development of this region are the focus and the purpose of this study. The Middle East and, in particular, the Arab Gulf States, is a region where there has been rapid development and change, as well as environmental calamity resulting from the specter of war. It is against this background that this research is set. More explicitly, we deal with the question: what are the incentives, options, and obstacles to technology transfer to the Arab Gulf countries?

The Arab Gulf countries, also called the Arab states of the Persian Gulf, is a term that refers to the six monarchial states of Saudi Arabia, Kuwait, Bahrain, Qatar, United Arab Emirates (UAE), and Oman. Those countries are best known for producing and exporting oil, where the oil revenues constitute an average of 80 percent of these countries' GDP. These countries also enjoy one of the highest GDP per capita in the world. Qatar and UAE are top of the list with annual GDP per capita of $\$ 70,651$ and $\$ 52,574$, respectively. On the other side, although Saudi Arabia has the highest GDP in the region, its GDP per capita comes in about $\$ 18,903$ (WDI, 2009).

The oil industry has a significant impact on the entire region, both through the wealth that it generates and through the movement of labor. IMF (2011) that during the past decade, the Arab Gulf oil exporters' states have created many jobs. Job creation was mainly in the private sector and mostly for expatriates. Most of the countries in the region have undertaken efforts to diversify their economies in recent years. The success of efforts to diversify the economy will primarily depend on the effectiveness of reforms in education, stepped-up training for nationals, and enhancing productivity (Hyman, 2007).

To achieve their goals, the Arab Gulf States encourages MNEs to go and invest in the region. This started a long time ago in the petroleum discovery and processing oil 
fields. Lately, UAE has formed a free zone in Dubai encouraging many MNEs to invest in Dubai.

This paper will review prior research regarding technology transfer issues, incentives, options, and obstacles. The next section will derive the research framework which is adapted from the vast literature on technology transfer. In the third section, we will present research methodology, including research instruments to collect data from respondents. The fourth section presents the results of the survey analysis and assessment of technology transfer to the Arab Gulf region and its effectiveness. The final session discusses the implications of this study.

\section{Review of literature}

The technology transfer literature has pointed out to various transmission mechanisms through which technology can spillover to other countries. These mechanisms include:

-movement of goods through international trade;

-movement of capital through inward and outward FDI;

-movement of people through migration, travel, and foreign education of students and workers;

-international research collaboration;

-diffusion of disembodied knowledge through media and internet; and -integration into global value chains (GVC) to benefit from the foreign technology transferred within the supply chain (Fu et al., 2011).

Of all of the above, FDI is considered the major vehicle for transferring technology to developing countries. In fact, MNEs are regarded as the major driver of R\&D in the world (Fu et al., 2011). Currently, estimated annual flows of FDI via MNEs exceed $\$ 232$ billion and the total stock exceeds $\$ 6$ billion (OECD, 2010; Chen and Lovvorn, 2011).

Previous literature generally distinguished two major channels along which technology diffusion can occur between MNEs and host country firms (Javorcik, 2010; Gorg and Greenaway, 2003; Blalock and Gertler, 2009). The first is the horizontal technology diffusion. The MNEs' entry to the domestic market brings various positive externalities to the local firms through different mechanisms.

The second channel is the vertical linkage which is the most compelling in the literature. In this case, the MNEs assist their suppliers and customers in different aspects, such as quality control or product management. Crispolti and Marconi (2005) called this type of diffusion active technological spillover as it occurs because the innovation and learning are primarily conscious and purposive (Lin and Saggi, 2007). 
Motohashi and Yuan (2010) and Le and Pomfret (2011) examined the role of both horizontal and vertical linkages in technology spillover to domestic firms in China and Vietnam. While the former study finds no evidence of horizontal spillover in China and mixed evidence on vertical spillover depending on the industry investigated, the latter study findings suggest a positive influence of vertical linkages in transferring technology to local firms. But, the effect of the horizontal presence of MNEs on the productivity of domestic firms is negative. This suggests that the potential gains to the local firms from technology transfer via vertical linkages are more than offset by the competition induced by the entry of MNEs.

Blackman (1999) discussed theories of technology diffusion from an economic standpoint. He demonstrated that these theories fall into four different categories: epidemic models, rank models, order models, and stock models. In recent years, dynamic models of collaborative relationships such as the theory of competitive advantage (Porter, 1987) model of collaboration across lines of business and across borders (Das and Teng, 2000), a resource-based perspective (Barney, 1991, 2011), have begun to emerge with emphasis on competitive cooperative urgency as a result of rapid technological changes and global competitive pressure. Thompson et al. (2012) suggested that transfer of technology through strategic alliance venture and strategic fit relationships through value chain can achieve a consolidated performance greater than the sum of what the business can earn pursuing independent strategies.

Furthermore, knowledge transfer vial GVC has been a focus of the literature. The value chain, as reported in the GVC initiative website, describes the full range of activities that firms and workers do to bring a product from its conception to its end use. This includes activities such as design, production, marketing, distribution, and support to the final consumer (Saliola and Zanfei, 2009).

In general, MNEs try to achieve efficiency through minimizing cost and maximizing their economies of scale, while reducing duplication. A new foreign market usually offers a potential for extension for MNEs. Notably, it is a large growing market with relatively high purchasing power and cheap labor. MNEs invest, also, in different locations in order to bypass protection in the importing countries, as well as bypass high transportation costs. For example, Japanese corporations located auto assembly plants in the USA to bypass such protection. They may, also, get different advantages from host countries such as tax holidays, subsidized industrial infrastructure, and duty exemptions (Root, 1984; Wang, 2009).

Incentives to engage in overseas investment are also influenced by labor market institutions (unions) in the home country. Lommerud et al. (2010) argue that if workers in their home country are collectively organized, incentives for technology transfers are governed by firms' desires to curb union power.

\section{Challenges to technology transfer}


Empirical research points to a number of different factors that often hinder technology diffusion in a host country. Some of these factors are related to the host country's firms' capabilities. The fundamental factor in literature is the "absorptive capacity" of the recipient country, which is the ability of the local firms to learn, adopt, and assimilate the new technologies (Cipollina et al., 2011; Blalock and Gertler, 2004). The absorptive capacity is mainly affected by the domestic human capital and the level of education in the domestic country. Borensztein et al. (1998) and Crispolti and Marconi (2005) argue that there exists a human capital threshold below which a recipient country will not be able to benefit from technology transfer. Following the same line, Xu (2000) demonstrates that most of the less developed countries do not reach that level.

Andrzej (2009) pointed out that the lack of own resources and lack of innovative culture and mentality among employees are among factors that adversely influence technology diffusion in developing countries. This supports Rodrigues' (1985) study when he argued that there is a resistance to change among local citizens, especially in less developed, agricultural societies:

A problem which many managers face is that new technology is often restricted [...] That is, managers often face difficulties in implementing new ideas [...] As a result, they must plan a change.

Another set of factors that influence technology transfer is the quality of the host countries' institutional framework. This varies from political stability, corruption, and risk of expropriation, to economic stability and degree of economic freedom, to the strength of intellectual property rights (Andrzej, 2009).

\section{Research framework}

The review of previous research provides a foundation for developing the conceptual model shown in Figure 1. The model illustrates relationships among constructs of interest with both mediating and moderating relationships, which constitute the fit among a firm's technology transfer posture (TTP) strategies to transfer technology to the Arab Gulf States and environment (external and internal). The relationship between TTP and effectiveness is mediated through international strategies to transfer technology, and the relationship between TTP and the strategies is moderated by environmental variables. The model identifies several variables including the independent variable which includes dimensions of TTP and effectiveness dimensions which are based on Likert's (1973) profile of organizational characteristics - the dependent variable. The casual linkage among these variables is assumed to influence technology transfer effectiveness (performance, adaptability, and satisfaction) as shown in Figure 1.

The claims of proponent of technology transfer suggested several research questions that guided this investigation of incentives, options, and challenges to 
technology transfer to the Arab Gulf region, and the examination of the relationships between technology transfer initiatives and organizational effectiveness:

RQ1. What are the incentives of technology transfer to multinational corporations? RQ2. What are the options to transfer technology to the Arabian Gulf region?

RQ3. What are the challenges to technology transfer to the Arabian Gulf region?

RQ4. Do technology transfer initiatives achieve their stated objectives of improving organizational effectiveness?

RQ5. Will former expatriates report positive assessments of technology transfer initiatives to the Arab Gulf countries?

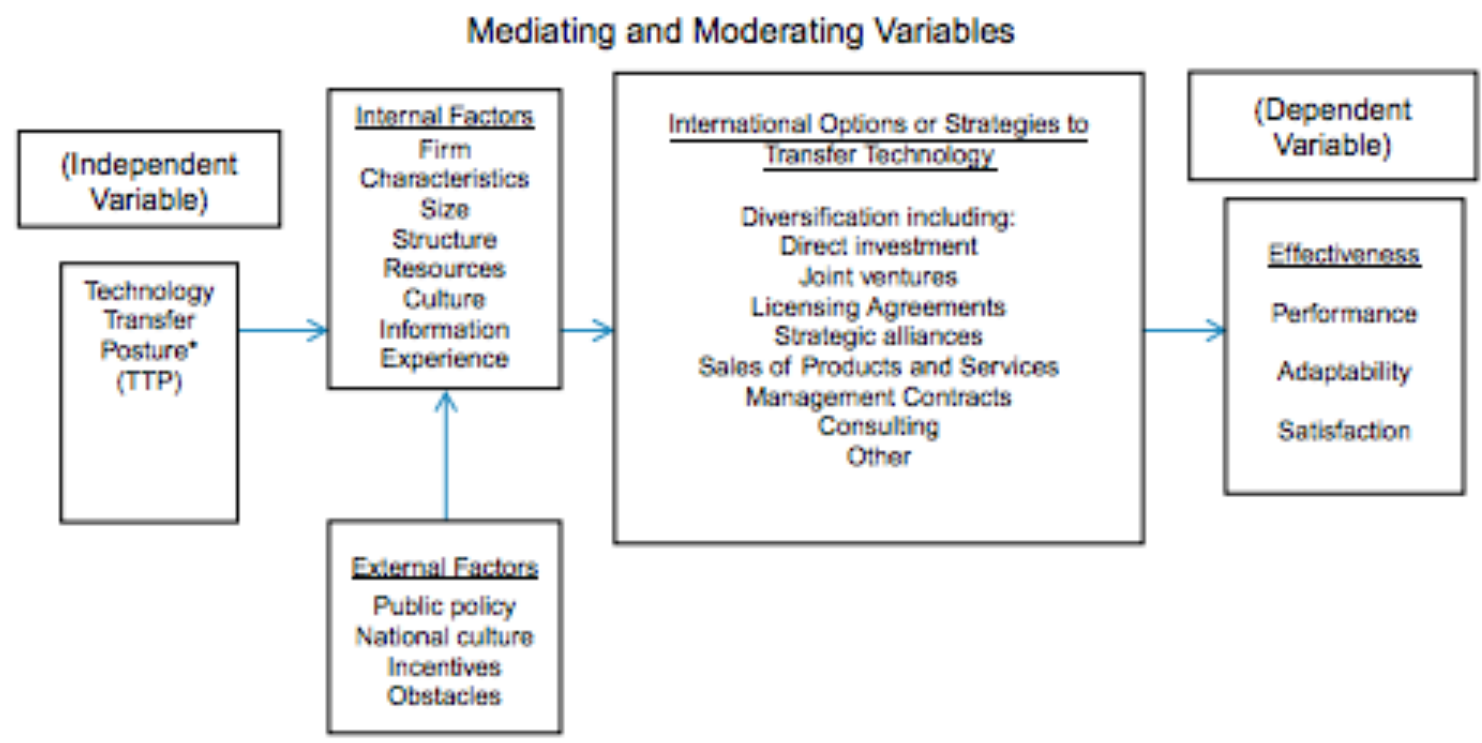

Notes: *Technology transfer refers to providing capital equipment, machinery, and products to another country. It also includes the implementation process and strategies that make a product successful in the market place. (Blalock and Gertler, 2009; Chen and Lovvorn, 2011)

Figure 1. Conceptual model of technology transfer - strategy-effectiveness relationship

This study investigates these five questions and offers recommendations to achieve the long-term objectives of technology transfer, which hopefully will be beneficial to the Arab Gulf nations as well as to the multinational corporations and industrial countries.

\section{Methodology}

In order to answer the above questions, a survey of technology transfer initiatives and effectiveness was developed and distributed to 400 former expatriates throughout the USA who were employed by several American-based multinational corporations in the Arab Gulf States. The Arab Gulf States refers to the six monarchial states of Saudi Arabia, Kuwait, Qatar, UAE, Bahrain, and Oman. 
Respondents were asked to provide their perceptions of technology transfer initiatives, incentives, options, challenges, and other observations. In addition, respondents were questioned about their levels of cultural adaptation while they were on assignments in the Arab Gulf States. Based on the Cross-cultural Adaptability Inventory instrument which was designed and checked for reliability and validity by Kelly and Meyers (1995), they were asked to assess the impact of the effectiveness of technology transfer initiatives on their organizational effectiveness and on the region as a whole.

The names of individuals were generated randomly from several international directories and associations, including the Association for International Research, Inc., Arab American University Graduate Association, and from several executive search agencies in the USA. Study participants were randomly selected to represent a range of organizational types, sizes, and a variety of positions within their organizations. Survey respondents included top-level executives, mid-level managers or first-line supervisors, bank directors, hospital administrators, construction developers, small-and medium-size business owners, entrepreneurs, and university leaders and educators. These respondents worked in areas of water, electrical, telecommunications, health, and petrochemical operations. These are knowledge-based activities. Surveys lasted 45 minutes using telephone calls, as well as hand delivered and collected surveys, and sometimes employed in-depth interviews with a few expatriates. A total of 195 questionnaires were returned for a response rate of 48 percent. 29 questionnaires were not acceptably completed, thus reducing the response rate to 41 percent. The remaining 166 usable questionnaires and the responses were analyzed in this study.

\section{Measures}

The questionnaire used in this study was developed by a group of researchers who have extensive work and research experience in technology transfer and have worked with several multinational corporations. The three-page questionnaire was divided into five main parts. The first part consisted of items dealing with incentives to industrial countries and multinational corporations to transfer technology to the Arab Gulf States as perceived by former expatriates. The second asked the respondents to list and rank options used to transfer technology to the Gulf region. Responses are on a four-point scale anchored by extremes of major incentives and not incentive responses. The third part consisted of items dealing with obstacles and problems to transfer technology to the Arab Gulf States. Responses are on four-point scales anchored by extremes of major obstacles and not obstacle responses. The fourth part consisted of items to assess the impact of technology transfer on overall organizational effectiveness and the value of technology transfer initiatives to Arab Gulf countries using Likert's (1973) profile of organization characteristics. The fifth part consisted of demographic characteristics of the respondents.

The reliability of scales used in this study, as estimated by applying the Cronbach's $\underline{\alpha}$ formula to the mean inter-item correlation, was 0.72 . The question of how large the 
coefficient $\alpha$ should be for an item to be reliable is not consistent among researchers; however, some consider $\alpha$ at 0.70 to be a good criterion for adequate scale reliability (Stockburger, 2007).

Follow-up interviews were also conducted with 24 former expatriates who were selected randomly from a list of 160 former expatriates who had previously completed and returned questionnaires. The purpose of the interviews was to obtain a deeper perspective of the effects of technology transfer efforts, as well as to investigate the incentives, options, and obstacles to transfer technology to the Arab Gulf region.

\section{Results and analysis}

\section{Demographic characteristic of respondents}

As indicated earlier, the incentives, options, obstacles, and assessments of impact of transfer technology on the Arab Gulf States were investigated by 160 former expatriates. Subjects occupied managerial positions as top-level executives, midlevel managers, or first-line supervisors.

The average subject was 44 years old, had at least four years of managerial experience in the Arab Gulf States, and had a baccalaureate degree. 54 percent of subjects were engaged in petrochemicals and oil operations, 36 percent in computer and banking industries operations, and 10 percent were engaged in construction projects throughout the Gulf region. A demographic analysis of the survey respondents is provided in Table I.

\section{Incentives for technology transfer}

The questionnaire listed eight incentives for industrial countries and multinational corporations to transfer technology to the Arab Gulf States and required that respondents check all applicable answers and specify any other incentives they may consider appropriate. The responses are shown in Table II.

It can be clearly seen that access to cheap and abundant energy and feedstock sources is ranked first among all of the incentives. The two following are availability of ample capital resources and availability of modern transportation and communications infrastructures in the Arab Gulf States. This coincides with many economists' claims that a host of multinational corporations, mainly American, European, and Japanese, are helping, for example, Saudi Arabia, develop new petrochemical industries. Truell (1984) and the IMF (2011), for example, pointed out the fact that with the help of foreign corporations and a good deal of its own cash, Saudi Arabia will soon become one of the biggest exporters of petrochemicals, the materials used to make plastics, paints, artificial fibers, fertilizers, and much more. In addition, the Arab Gulf region is rapidly becoming the leading supplier of crude oil to most of the industrial nations (WDI, 2009; Hyman, 2007). 
Strategies for assuring access to the oil fields will vary. The USA, with its recent military victory over Iraq in the Persian Gulf, was able to provide direct military protection. Japan, through investment and by allowing Gulf investment in "downstream" processing in Japan, itself, seeks to assure its access through economic leverage. Japan is entirely dependent on imported oil, mainly from the Persian Gulf. The Gulf region accounted for 67-71 percent of all Japan's imported oil in 2010 (WDI, 2009; Hyman, 2007).

\begin{tabular}{|c|c|c|}
\hline Demographic characteristics & Respondents total numbers & $\%$ \\
\hline \multicolumn{3}{|l|}{ Sex } \\
\hline Male & 150 & 90 \\
\hline Female & 10 & 6 \\
\hline Did not include gender & 6 & 4 \\
\hline \multicolumn{3}{|l|}{ Age } \\
\hline Under 30 & 20 & 12 \\
\hline $31-40$ & 90 & 54 \\
\hline 41.50 & 40 & 24 \\
\hline Over 50 & 16 & 10 \\
\hline \multicolumn{3}{|l|}{ Education } \\
\hline High school or two-year degree & 40 & 24 \\
\hline Baccalaureate degree & 78 & 47 \\
\hline Graduate degree & 48 & 29 \\
\hline \multicolumn{3}{|l|}{ Years of experience } \\
\hline 1.4 hears & 100 & 60 \\
\hline $5-10$ years & 45 & 27 \\
\hline 11.15 years & 15 & 9 \\
\hline Over 20 years & 6 & 4 \\
\hline \multicolumn{3}{|l|}{ Nature of job and rank } \\
\hline Technical supervisor & 40 & 24 \\
\hline Department manager & 85 & 51 \\
\hline Division chief & 30 & 18 \\
\hline Chief executive officer & 6 & 7 \\
\hline Consulting duties & 5 & 3 \\
\hline \multicolumn{3}{|l|}{ Nature of business-operation } \\
\hline Manufacturing & 90 & 54 \\
\hline Service (health, education, telecommunication) & 60 & 36 \\
\hline Construction & 16 & 10 \\
\hline \multicolumn{3}{|l|}{ Reasons for leauing foreign assignment } \\
\hline Personal reasons & 100 & 60 \\
\hline Transferred to USA & 44 & 27 \\
\hline Promoted to different job & 22 & 13 \\
\hline Note: $n=166$ & & \\
\hline
\end{tabular}

Table I. Summary of demographic characteristics for survey respondents 


\begin{tabular}{llc}
\hline Rank & Incentives & Percent of respondents \\
\hline 1 & Cheap and abundant energy and feedstock sources & 58.2 \\
2 & Ample capital resources & 54.6 \\
3 & $\begin{array}{l}\text { Modern transportation and communications } \\
\text { infrastructures }\end{array}$ & 51.2 \\
4 & $\begin{array}{l}\text { Reasonably consistent and liberalized industrial } \\
\text { regulations and policies }\end{array}$ & 46.2 \\
5 & Wide range of incentives offered to investors & 42.1 \\
6 & Security arrangements by the USA for the region & 20.1 \\
7 & after the trauma of war & 20.1 \\
8 & Skilled nonunionized foreign labor force & 30.4 \\
\hline
\end{tabular}

Table II. Incentives for industrial countries and multinational corporations to transfer technology to the Arab Gulf States

Other incentives listed as aiding technology transfer to the Arab Gulf region were recent liberalization of industrial regulations and policies in some of the Gulf nations, and a wide range of incentives offered to investors mainly from the USA which will contribute to the Gulf's attractiveness.

One of the ironies of the Persian-Arabian Gulf is that wars and devastation have often been the prelude to economic progress. Fluidity and conflict often mean opportunity. Cost estimates for rebuilding Kuwait and Iraq after the wars began to surface in late 1990 and in 2010. Initially, these ranged between $\$ 100$ and $\$ 300$ billion (OECD, 2010; WDI, 2009; CIA, 2010). To date, US companies have benefitted most. There are two main reasons for this: first, because of the USA's pre-eminent role in the coalition to free Kuwait and Iraq, and second because of the decision by the US Government to encourage US companies to transfer technology and knowhow not only to Kuwait and Iraq, but also to Saudi Arabia and other Arab Gulf States.

\section{Options of technology transfer}

The questionnaire listed 12 options used to transfer technology to the Arab Gulf States and required that respondents check all applicable answers and specify any other options used that they consider appropriate. The responses are shown in Table III.

It can be clearly seen that despite the fact that many former expatriates who worked in the Arab Gulf States are not sure of the best option to transfer technology to the Arab Gulf States, direct investment and training of employees by multinational corporations are ranked first among all of the options. The three following are sales of products, materials, and components, training of users and product services, and 
turn-key operations. This coincides with many academicians' claims that multinational corporations are unquestionably the dominant institutions transferring industrial technologies and know-how skills across national borders (Fu et al., 2011; OECD, 2010; Javorcik, 2010).

\begin{tabular}{rlc}
\hline Rank & Options & Percent of respondents \\
\hline 1 & Direct investment and training of employees by & 62.4 \\
& multinational corporations & \\
2 & Sales of products, materials, and components & 56.2 \\
3 & Training of users and product service & 52.1 \\
4 & Turn-key operations & 51.0 \\
5 & Production sharing & 40.1 \\
6 & Management contracts & 32.8 \\
7 & Subcontract arrangement & 28.2 \\
8 & Consulting & 18.2 \\
9 & Joint ventures & 14.2 \\
10 & Green-field development & 9.1 \\
11 & Licensing agreements & 8.2 \\
12 & Research and development corporation & 6.1 \\
13 & Other & 5.4 \\
\hline
\end{tabular}

Table III. Options to transfer technology to the Arab Gulf States

Other options listed and used to transfer technology to the Arab Gulf States were production sharing, management contracts, consulting, joint ventures, strategic alliances, green-field development, licensing agreements, and research and development corporation.

\section{Obstacles to technology transfer in general}

According to the survey (Table IV), most of the respondents (70-80 percent) believe that shortage of manpower, lack of industrial management expertise and technical skills among the national population, bureaucratic constraints, complex legal codes, such as over-rigid work permit restrictions, dependence on foreign expertise, lack of integration of women into the labor force, and lack of political stability and security in the Gulf region are the major obstacles to transfer technology to the Arab Gulf States. Furthermore, more than 43 percent of the respondents believe that an ineffective marketing system and insufficient information base and research capabilities are among the moderate obstacles to technology transfer to the Gulf States. At the same time, however, more than 50 percent of the respondents view traditional values, customs, and religion as minor obstacles to economic diversification in the region. In addition, more than 30 percent of the respondents believe that industrialization efforts are hampered by relatively small local markets and limited commercial bank lending. About 33 percent of the respondents, however, state that building huge petrochemical projects in the Arab Gulf nations is 
not an obstacle to technology transfer, but rather a major effort to achieve economic development in the region (Truell, 1984; IMF, 2011).

\begin{tabular}{|c|c|c|c|c|c|}
\hline Perceptions & $\begin{array}{c}\% \\
\text { Major } \\
\text { obstacle }\end{array}$ & $\begin{array}{c}\% \\
\text { Moderate } \\
\text { obstacle }\end{array}$ & $\begin{array}{c}\% \\
\text { Minor } \\
\text { obstacle }\end{array}$ & $\begin{array}{c}\% \\
\text { Not an } \\
\text { obstacle }\end{array}$ & $\begin{array}{c}\text { Total } \\
(n)\end{array}$ \\
\hline $\begin{array}{l}\text { Shortage of manpower and the lack of } \\
\text { industrial management expertise and } \\
\text { skills among the national population }\end{array}$ & $n=134$ & $\begin{aligned} n= & 17 \\
& 10.2\end{aligned}$ & $n=10$ & $n=5$ & 166 \\
\hline Bureaucratic constraints, complex & $n=130$ & $n=20$ & $n=11$ & $n=4$ & 165 \\
\hline $\begin{array}{l}\text { legal codes such as over rigid work } \\
\text { permit restrictions }\end{array}$ & 78.7 & 12.1 & 6.7 & 2.5 & \\
\hline $\begin{array}{l}\text { Dependence on foreign expertise and } \\
\text { lack of integration of women into the } \\
\text { labor force }\end{array}$ & $n=144$ & $n=14$ & $n=6$ & $\begin{aligned} & n= 2 \\
& 1.2\end{aligned}$ & 166 \\
\hline $\begin{array}{l}\text { Ineffective marketing system and an } \\
\text { insufficient information base and } \\
\text { research capabilities }\end{array}$ & $\begin{aligned} n= & 20 \\
& 11.5\end{aligned}$ & $\begin{aligned} n= & 72 \\
& 44.0\end{aligned}$ & $\begin{aligned} n= & 24 \\
& 14.5\end{aligned}$ & $\begin{aligned} n= & 50 \\
& 30.0\end{aligned}$ & 166 \\
\hline $\begin{array}{l}\text { Traditional values, customs, and } \\
\text { religion }\end{array}$ & $\begin{aligned} n= & 30 \\
& 18.1\end{aligned}$ & 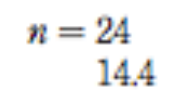 & $n=\frac{92}{55.4}$ & 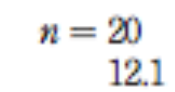 & 166 \\
\hline Relatively small local markets & $\begin{aligned} n= & 20 \\
& 12.1\end{aligned}$ & $\begin{aligned} n= & 34 \\
& 20.4\end{aligned}$ & $\begin{aligned} & n= 86 \\
& 520\end{aligned}$ & $\begin{aligned} n= & 26 \\
& 15.6\end{aligned}$ & 166 \\
\hline Limited commercial-bank lending & $\begin{aligned} n= & 40 \\
& 24.2\end{aligned}$ & $\begin{array}{l}n=60 \\
36.4\end{array}$ & $n=50$ & $n=15$ & 165 \\
\hline $\begin{array}{l}\text { Resistance to new technology by local } \\
\text { residents }\end{array}$ & $\begin{aligned} n= & 38 \\
& 23.0\end{aligned}$ & $\begin{aligned} n= & 44 \\
& 25.7\end{aligned}$ & $\begin{aligned} & n= 50 \\
& 30.3\end{aligned}$ & $n=\frac{33}{20.0}$ & 165 \\
\hline $\begin{array}{l}\text { Industrial projects are beased on } \\
\text { nationalistic needs rather than on } \\
\text { global competitive advantage }\end{array}$ & $\begin{aligned} n= & 40 \\
& 24.1\end{aligned}$ & $\begin{aligned} n= & 50 \\
& 30.1\end{aligned}$ & $\begin{aligned} n= & 20 \\
& 12.1\end{aligned}$ & $n=\begin{aligned} 56 \\
33.7\end{aligned}$ & 166 \\
\hline $\begin{array}{l}\text { Conduct and practices of multinational } \\
\text { corporations in the Arab Gulf region }\end{array}$ & $n=14$ & $n=16$ & $n=18$ & $n=118$ & 166 \\
\hline $\begin{array}{l}\text { Several industrial countries may } \\
\text { prohibit the sale of critical technology } \\
\text { to the Gulf region }\end{array}$ & $\begin{aligned} n= & 72 \\
& 44.0\end{aligned}$ & $\begin{aligned} n= & 19 \\
& 11.5\end{aligned}$ & $\begin{aligned} n= & 24 \\
& 14.5\end{aligned}$ & $\begin{aligned} n= & 50 \\
& 30.0\end{aligned}$ & 165 \\
\hline $\begin{array}{l}\text { Lack of political stability and security } \\
\text { in the Arab Gulf region }\end{array}$ & $n=130$ & 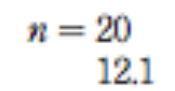 & $n=11$ & 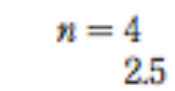 & 165 \\
\hline
\end{tabular}

Table IV. Former expatriates' perception of obstacles to transfer technology to the Arab Gulf States

\section{Obstacles related to multinational corporations}

Of the respondents to the survey, 71.1 percent reported that the conduct and practices of multinational corporations were not obstacles to transfer technology and know-how to the Arab Gulf States. It appears that these former expatriates have very favorable attitudes toward multinational corporations, and only a small percentage, 8 percent, think that the conduct of multinational corporations, mainly 
the oil companies, is an obstacle to transfer technology and know-how skills to the host nations in the Gulf region. However, when it comes to the question of industrial countries' restrictions on the sale of critical technology, such as advanced computers and arms to the Gulf region, there are mixed answers. About 44 percent of the respondents stated that restrictions on the sale of critical technology to countries in the Gulf region is a major obstacle to technology transfer, while 30 percent felt that some of the restrictions placed by industrial countries on critical technology was not an obstacle to technology transfer, but rather implemented to maintain peace and stability in the region.

\section{Assessment of technology transfer - interview findings}

In-depth interviews were conducted with 24 former expatriates who had previously completed and returned questionnaires. 90 percent of the interviewed former expatriates indicated that access to cheap and abundant energy and feedstock sources is ranked first among all incentives to transfer technology to the Arab Gulf nations. 60 percent of the interviewed respondents stated that the Gulf States possess state-of-the-art transportation and communications systems, ample capital resources, liberal industrial regulations and policies, and a wide range of incentives offered to industrial countries and multinational corporations to transfer technology to the Gulf region.

70 percent of the former expatriates considered direct investment and training of employees by multinational corporations one of the best and most effective options to transfer technology to the Arab Gulf States. 55 percent of the former expatriates expressed support for the role of the multinational corporations in helping the Gulf States develop their economies. At the same time, however, ten former expatriates felt that the Gulf States were better off concentrating on oil-related industries such as petrochemical technologies and investment of their capital resources in the USA, Europe, and Japan, rather than on labor intensive industries. Six former expatriates, however, were unconvinced that the Gulf nations were capable of developing their own industries and absorbing new technologies.

A majority of 75 percent of interviewed respondents believed that industrialization efforts were hampered by a relatively small local market, lack of industrial management expertise, and technical skills among the national population in the Gulf region. Furthermore, 58 percent of the former expatriates felt that dependence on foreign expertise, lack of integration of women into the labor force, and ineffectiveness of the Gulf governments to address serious demographic problems were among the major obstacles to transfer technology to the Gulf region.

Further analysis of the relationship between technology transfer initiatives and organizational effectiveness was done with the use of multiple regression analysis. The results of this analysis indicate a positive relationship between measures of TTP and its strategies, mainly direct investment, joint ventures, and strategic alliances, and organizational effectiveness as reflected in the multiple regression ratios. The 
results show that 55 percent of the variations in performances, 40 percent of the variations in adaptability, and 62 percent of the variations in satisfaction are explained by linear regression on the technology transfer dimensions between a multinational corporation and its direct foreign investment and joint venture dimensions. The F-ratios indicate that linear associations are statistically significant at p , 0.05. These findings support previous studies (Fu et al., 2011; Javorcik, 2010) regarding the impact of technology transfer on developing countries.

\section{Limitations}

There are obvious limitations to the self-reported data collected in this study and to the interview responses from key multinational professionals. The sample for this study is small in size and coverage and may not be representative of the whole population in the Arab Gulf States. Each state has its own circumstances and internal issues; therefore, it is not wise to generalize these findings. In addition, a survey methodology was also used which is susceptible to both misinterpretation and common variance. Despite these limitations, this exploratory empirical investigation provides a tentative avenue for increasing the probability of success regarding technology transfer among the Arab Gulf States, and it identifies areas that need further research. Further work is needed regarding the impact of different technology transfer strategies on the development and enhancement of the local work force in the Gulf region and to identify the best strategy to enhance economic growth rate in the region.

\section{Implications}

In short, regardless of the nature of the political and economic systems in the Arab Gulf countries, all share two fundamental traits: a desire for speedy development to emulate the economic and technological levels of the more advanced industrial countries, and assertiveness about their newly-won sovereignty. Their objectives are to sustain their national development, broaden their industrial base, and create revenue that is shockproof. A large part of this process will be the diversification of the oil and gas industries to create support downstream and to related industries at home. In order to accomplish these objectives, Gulf nations must have a good grounding in technical education, engineering, and basic science, and must address serious demographic problems. Quick-fix remedies could result in a short-term financing drain and greater resistance by locals that could adversely affect industrialization efforts. Technology transfer cannot be seen as the only resort for attaining growth rates. Education, innovation, and domestic research and development processes are necessary to achieve economic growth.

\section{Conclusions}

Several significant conclusions emerged as a result of this study. First, it is clear that former expatriates do see some benefits of technology transfer to the Arab Gulf States, and they believe that technology transfer will contribute to the region's 
economic growth and stability in the long run. Furthermore, a sizable majority of these former expatriates believe that the Arab Gulf States possess cheap and abundant energy and feedstock resources, ample capital resources, state-of-the-art transportation and communications infrastructures, reasonably consistent industrial regulations and policies, and a wide range of incentives offered to investors that contribute to the Gulf's attractiveness.

Second, the research findings indicate that technology transfer to the Arab Gulf nations to industrialize their economies will also be beneficial to the multinational corporation, Europe, the USA, and Japan, among other industrialized countries in terms of oil security and access to oil reserves. The Gulf's oil fields account for some 65 percent of the world's known recoverable oil reserves. The Gulf States also account for 65-70 percent of the world's excess production capacity. As for the USA, despite its role as one of the world's biggest oil producers, dependency on imported oil has been growing. Furthermore, adapting American technologies and standards will mean an increased demand for American products and American manufacturing processes. Third, a large majority of former expatriates are not sure that the indigenous in the Arab Gulf States are capable of absorbing new technology and eventually setting up entrepreneurial ventures on their own. Furthermore, industrialization efforts in the Gulf Region are hampered by a relatively small local market, an ineffective marketing system, and an insufficient information base and research capabilities. The lack of industrial management expertise and technical skills among the national populations translates into a dependence on foreign expertise. Investors must also overcome bureaucratic constraints, complex legal codes, and resistance to new technology by local residents. Through technical education, engineering, basic science and management developments, these constraints can be reduced.

Fourth, it appears that most of the former expatriates surveyed have very favorable attitudes towards multinational corporations, and only a small number of these employees think that the conduct of the multinational corporations is an obstacle to transfer technology to the host nations in the Gulf region. This coincides with many academicians' claims that multinational corporations are unquestionably the dominant institutions transferring industrial technologies and know-how skills across national borders.

Fifth, with the conclusion of the crisis and wars in Kuwait and Iraq, many former expatriates expressed strong support for the USA' military involvement and security commitments to the Gulf region. Furthermore, they felt that the US action and the current regional and global geopolitical atmosphere will have positive effects on the Gulf economies and will encourage transfer of technology to the Gulf region by multinational corporations and industrial countries in the long run. 


\section{References}

Andrzej, J. (2009), “Barriers for technology transfer: the case of a country in transition", Journal of Technology Management in China, Vol. 4 No. 2, pp. 119-131.

Barney, J.B. (1991), "From resources and sustained competitive advantage", Management Science, Vol. 32 No. 2, pp. 123-124.

Barney, J.B. (2011), Gaining and Sustaining Competitive Advantage, 4th ed., Pearson Education, Upper Saddle River, NJ

Blackman, A. (1999), "The economics of technology diffusion: implications for climate policy in developing countries", Discussion Paper No. 99-42, Resources for the Future.

Blalock, G. and Gertler, P. (2004), "Welfare gains from foreign direct investment through technology transfer to local suppliers", Journal of International Economics, Vol. 74 No. 2, pp. 402-421.

Blalock, G. and Gertler, P. (2009), "How firm capabilities affect who benefits from foreign technology", Journal of Development Economics, Vol. 90 No. 2, pp. 192-199.

Borensztein, E., DeGregorio, J. and Lee, J. (1998), "How does foreign direct investment affect economic growth?", Journal of International Economics, Vol. 45 No. 1, pp. 115-135.

Chen, J. and Lovvorn, A. (2011), "The speed of knowledge transfer within multinational enterprises: the role of social capital", International Journal of Commerce \& Management, Vol. 21 No. 1, pp. 46-62.

Chiesa, V. and Manzini, R. (2009), "Managing knowledge transfer within multinational firms", International Journal of Technology Management, Vol. 12 No. 2, pp. 16-28.

CIA (2010), "The world Facebook", Central Intelligence Agency, available at: www.Pbs.org/wgbh/globalconnections/mideast/themes/science/index.html

Cipollina, M., Giovannetti, G., Pietrovito, F. and Pozzolo, A. (2011), "FDI and growth: what cross-country industry data say", available at:

http://ssrn.com/abstract $1 / 41836243$

Crispolti, V. and Marconi, D. (2005), "Technology transfer and economic growth in developing countries: an econometric analysis", Working Paper No. 564, Economic Research Department, Bank of Italy. 
Das, T.K. and Teng, B.S. (2000), "A resource-based theory of strategic alliances", Journal of Management, Vol. 26 No. 1, pp. 31-61.

Dinopoulos, E. and Segerstrom, P. (2010), "Intellectual property rights, multinational firms and economic growth", Journal of Development Economics, Vol. 92 No. 1, pp. 13-27.

Fu, X., Pietrobelli, C. and Soete, L. (2011), “The role of foreign technology and indigenous innovation in emerging economies: technological change and catching up", World Development, Vol. 39 No. 7, pp. 1204-1270.

Gorg, H. and Greenaway, D. (2003), "Much ado about nothing? Do domestic firms really benefit from foreign direct investment?", The World Bank Research Observer, Vol. 19 No. 2, pp. 171-197.

Hyman, K. (2007), "Middle east: economy”, Scholastic.com, available at: www.content.scholastic.com/browse/article.jsp?id $1 / 45896$

IMF (2011), Regional Economic Outlook Report: Middle East and Central Asia, IMF, Washington, DC.

Javorcik, B. (2010), Foreign Direct Investment and International Technology Transfer, Encyclopedia of Financial Globalization, available at: www.chch.ox.ac.uk/sites/default/files/Javorcik.pdf

Kelly, C. and Meyers, J. (1995), CCAI: Cross-cultural Adaptability Inventory, Pearson Reid, Chicago, IL, pp. 16-28.

Le, H. and Pomfret, R. (2011), "Technology spillover from foreign direct investment in Vietnam: horizontal or vertical spillovers?", Journal of the Asia Pacific Economy, Vol. 16 No. 2, pp. 62-88.

Likert, R. (1973), "Human resource accounting: building and assessing productive organizations", Personnel, June, pp. 8-24.

Lin, P. and Saggi, K. (2007), "Multinational firms, exclusivity, and backward linkages", Journal of International Economics, Vol. 71 No. 1, pp. 206-220.

Lommerud, K., Meland, F. and Straume, O. (2010), "North-south technology transfer in unionized multinationals", Working Paper Series No. 3273, CESifo.

Mansfield, E. (1975), "International technology transfer: forms, resource requirement, and policies”, American Economic Review, Vol. 65 No. 1, pp. 372-376.

Motohashi, K. and Yuan, Y. (2010), "Productivity impact of technology spillover from 
multinationals to local firms: comparing China's automobile and electronics industries", Research Policy, Vol. 39 No. 6, pp. 790-798.

OECD (2010), OECD Fact Book, OECD, Paris.

Porter, M.E. (1987), "From competitive strategy to cooperative strategy", Harvard Business Review, Vol. 65 No. 3, pp. 43-59.

Rodrigues, C. (1985), "A process for innovations in developing countries to implement new technology", Columbia Journal of World Business, Vol. 12 No. 4, pp. 21-28.

Root, F. (1984), Entry Strategies for International Markets, Lexington Books, New York, NY.

Saliola, F. and Zanfei, A. (2009), "Multinational firms global value chains and the organization of knowledge transfer", Research Policy, Vol. 38 No. 2, pp. 369-381.

Stockburger, D. (2007), "Multivariate statistics: concepts, models, and applications”, available at: www.psychstat.missouristate.edu/multoo.html (accessed March 3, 2009).

Thompson, A.A., Peteraf, M.A., Gamble, J.E. and Strickland, A.J. (2012), Crafting and Executing Strategy: The Quest for Competitive Advantage, 18th ed., McGrawHill/Irwin, Chicago, IL.

Truell, P. (1984), "Saudis have big plans in petrochemicals", The Wall Street Journal, Vol. 204, July 14, pp. 22-23.

Wang, M. (2009), "Manufacturing FDI and economic growth: evidence from Asian economics”, Applied Economics, Vol. 41 No. 8.

WDI (2009), CD Rom, World Development Indicators, World Bank Publications, Washington, DC.

Xu, B. (2000), "Multinational enterprises, technology diffusion, and host country productivity growth", Journal of Development Economics, Vol. 62 No. 1, pp. 477-493. 
